\title{
Probiotics and blood pressure: current insights
}

\author{
This article was published in the following Dove Press journal: \\ Integrated Blood Pressure Control \\ 25 February 2016 \\ Number of times this article has been viewed
}

\section{Aditya Upadrasta \\ Ratna Sudha Madempudi \\ Centre for Research and \\ Development, Unique Biotech \\ Limited, Alexandria Knowledge Park, \\ Shamirpet, Hyderabad, India}

\begin{abstract}
Gut microbiota play a significant role in host metabolic processes, and recent metagenomic surveys have revealed that they are involved in host immune modulation and influence host development and physiology (organ development). Initially, probiotics are identified as potential therapeutics to treat gastrointestinal disorders and to revitalize the disturbed gut ecosystem. Currently, studies are exploring the potential for expanded uses of probiotics for improving the health conditions in metabolic disorders that increase the risk of developing cardiovascular diseases such as hypertension. Further investigations are required to evaluate targeted and effective use of the wide variety of probiotic strains in various metabolic disorders to improve the overall health status of the host. This review addresses the causes of hypertension and the hypotensive effect of probiotics, with a focus on their mechanistic action.
\end{abstract}

Keywords: probiotics, hypertension, ACE, gut microbiota, metabolic disorders, metagenomics

\section{Introduction}

Probiotics have gained significant importance in the last few decades for their health promoting roles in the prevention and prophylaxis of various gut associated disorders, urogenital, and respiratory infections. ${ }^{1}$ They have also been shown to positively affect the host immune system through immunoglobulin production, and trigger cellmediated immune responses as a frontline of defense. ${ }^{2,3}$ Probiotics are described as "live microorganisms which when administered in adequate amounts confer a health benefit on the host". ${ }^{4}$ The therapeutic potential and antimicrobial spectra of probiotics is a complex and a multifactorial process which involves the production of organic acids, hydrogen peroxide, ${ }^{5,6}$ bacteriocins, bacteriocin-like inhibitory substances, ${ }^{7,8}$ short-chain fatty acids (SCFAs), conjugated linoleic acid (CLA), and $\gamma$-amino butyric acid (GABA) $)^{9-12}$ (Figure 1).

Many studies have elucidated the health benefits and clinical effects of probiotics in gastrointestinal abnormalities including irritable bowel syndrome, irritable bowel disease, gastric ulcers, rotavirus, traveler's and antibiotic-associated diarrhea, colorectal cancer, and in the alleviation of lactose malabsorption. ${ }^{13,14}$ Recently, probiotics have undergone scientific scrutiny for their potential in reducing the risk of cardiovascular diseases (CVDs) and they have been shown to be effective in improving the health conditions among the tested subjects with cardio-associated diseases. ${ }^{15-19}$ The estimated total number of adults with hypertension worldwide during the year 2000 was 1 billion and predicted to rise to 1.58 billion by the year $2025 .^{20}$
Correspond

Centre for Research and Development

Unique Biotech Limited, Alexandria

Knowledge Park, Phase-II, Plot-2,

Shamirpet, Hyderabad, 500078, India

Tel +9| 402375 I346

Fax +9| 402375 I345

Email sudha@uniquebiotech.com
Integrated Blood Pressure Control 2016:9 33-42

(c) (i) (5) 2016 Upadrasta and Madempudi. This work is published and licensed by Dove Medical Press Limited. The full terms of this license are avalable at https://www. (c) accessing the work you hereby accept the Terms. Non-commercial uses of the work are permitted without any further permission from Dove Medical Press Limited, provided the work is properly accessing the work you hereby accept the Terms. Non-commercial uses of the work are permitted without any further permission from Dove Medica
attributed. For permission for commercial use of this work, please see paragraphs 4.2 and 5 of our Terms (https://www.dovepress.com/terms.php).
Dovepress

http://dx.doi.org/10.2147/IBPC.S73246 


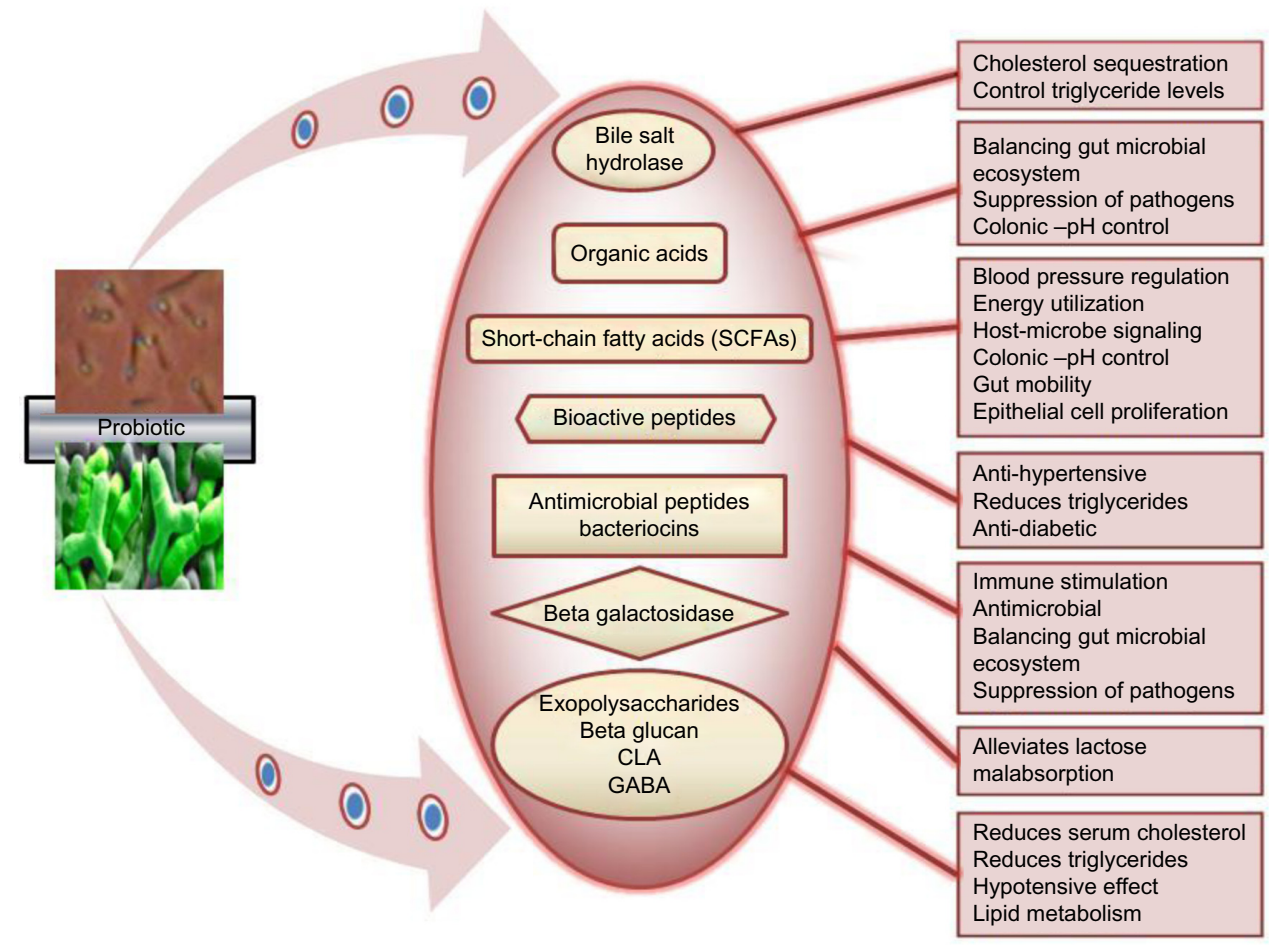

Figure I Probiotics and their metabolite-related health promoting functions. Abbreviations: CLA, conjugated linoleic acid; GABA, $\gamma$-amino butyric acid.

Certain probiotic strains such as lactobacilli and bifidobacteria can effectively produce SCFAs, CLA, GABA, ${ }^{12,21-23}$ and ACE inhibitory peptides, which have shown potential hypotensive effects. ${ }^{24-26}$ Growing public awareness of dietassociated health issues has fueled the functional foods concept, foods that provide specific health benefits over and above their nutritional value, ${ }^{10}$ which can be produced under controlled fermentation conditions or enriched with added nutrients. Functional foods enhance the overall nutritional status with added vitamins and minerals including probiotics and their biogenic metabolites. ${ }^{27}$ Many studies have shown the health benefits associated with the consumption of functional foods incorporated with probiotics, such as cheese, ${ }^{28}$ milk, fermented milk products, ${ }^{21,29,30}$ and non-dairy beverages. ${ }^{31}$

In this review we emphasize the biochemistry of hypertension, diet associated disorders, and the role of probiotics in controlling elevated blood pressure (BP) levels, nutritional programming, and the application of probiotic cultures in reducing the onset and development of CVD.

\section{Gut microbiology and human health}

Metagenomics has revolutionized the field of microbiology by paving the way for culture-independent assessment and exploration of microbial communities residing in complex ecosystems. The mammalian gastrointestinal tract (GIT) is among the most densely populated with complex microbial communities and the colon merely harbors a load of $\sim 10^{14}$ cells/host. ${ }^{32}$ The human intestinal microbiota plays a pivotal role in the host's digestive process, gut maturation, epithelial cell development, and a regulatory switch to innate immunity, thereby contributing to host health ${ }^{33}$ and many more functions yet to be revealed which are associated with the gut microbiota. The metabolic capacity of the core gut microbiome is so prodigious that it has been considered as the "virtual organ" of the GIT, ${ }^{34,35}$ and it is known to influence human health and disease susceptibility in different ways.

Microbial colonization of the host starts during birth, and the composition of the microbiota widely varies throughout host development. ${ }^{36,37} \mathrm{~A}$ variety of factors during and after birth, such as mode of birth (vaginal versus cesarean-section), feeding (breastfed or bottle fed), and antibiotics play a significant role in shaping the gut microbiota, ${ }^{38}$ which reflects their proximity in the health-disease state equilibrium during the growth and development of their host. ${ }^{39}$ Furthermore, the possible role of early colonizers during infancy and changes in their relative composition of the gut microbiota during childhood that can lead to the accumulation of body weight and obesity has been elucidated. ${ }^{40} \mathrm{~A}$ recent study revealed the presence of unique microbiome in the human placenta and its resemblance to their oral microbiome, ${ }^{41}$ suggesting that it is 
imperative to map the microbial networks residing at different niches to understand their role in health and disease.

\section{Intestinal dysbiosis, diet, and metabolic disorders}

Recent studies have revealed that many health maladies are as a result of significant perturbation in core gut microbial communities, and many parameters such as host-microbe crosstalk which are intrinsically linked to the microbial ecology and gut functionality. The influence of GIT microbiota composition and their possible link to obesity, ${ }^{42}$ diabetes, ${ }^{43,44}$ neural disorders, ${ }^{45,46}$ brain development, ${ }^{47}$ insulin resistance, and other metabolic disorders ${ }^{48}$ have been well documented. Furthermore, an aberration in the core-gut microbiota in TLR-5 deficient mice leads to the development of metabolic syndrome. ${ }^{49}$ Recently, more evidence has been accumulated by deciphering the role of gut microbiota in developing CVD. For example, gut microbiota metabolizes specific dietary nutrients which belong to the trimethylamine group (eg, choline, phosphatidylcholine, and L-carnitine) resulting in the formation of the pro-atherogenic compound called trimethylamine-N-oxide (TMAO), ${ }^{50,51}$ and the carnitine metabolic-pathway associated gene clusters are identified in the genomes of human microbiota. ${ }^{52}$ Altogether, compositional sequencing approaches coupled with transcriptomics studies extrapolated the microbe-host interaction and their interplay among various metabolic and biochemical pathways at the molecular level. However, information on the key role-players is still unclear and yet to be determined for modulation or to reprogram the microbial territories to overcome the health ailments.

There are many factors in developing hypertension, such as sedentary lifestyle, lipid and cholesterol metabolism (obesity), sodium sensitivity, personal habits (alcohol consumption, smoking), anxiety, stress, and vitamin D deficiency. ${ }^{22}$ There is direct evidence of the factors that control BP such as: a well programmed nutritional strategy and lifestyle, maintaining recommended body mass index (weight loss), reduced salt intake, "dietary approaches to stop hypertension"-type dietary pattern (vegetarian diet, more fruits, vegetables, and low-fat dairy products), increased potassium intake, and moderation of alcohol intake. ${ }^{53,54}$

It has been demonstrated that the risk of developing CVD was significantly lower in vegetarians when compared to omnivores. ${ }^{55-57}$ In this context, vegetarians had a significantly higher abundance of Bacteroides species and lower abundance of Prevotella species in their core gut microbiomes when compared to omnivores, and a reduced risk of develop- ing CVDs. ${ }^{58}$ Similarly, a study in men (aged between 41-57 years), whose diet intake chiefly includes vegetables and fruits showed a reduced risk of developing high BP. ${ }^{59}$ These studies indicate the importance of dietary habits and their influence on overall health status and GIT microbiota.

One way of modulating the gut microbiota is by the consumption of probiotics, in particular, products containing lactic acid bacteria. In this context, Lactobacillus spp. and Bifidobacterium spp. have been extensively studied as probiotic microorganisms, while other groups such as Enterococcus, Oenococcus, Propionibacterium, Bacillus, Escherichia coli, Clostridium butyricum, and some yeast strains, such as Saccharomyces boulardii, have also been used. In recent years, functional foods containing probiotics have become popular within the food industry due to the heightened awareness of consumers toward these health-promoting foods. ${ }^{60}$ Nutritional programming to manipulate the composition of the intestinal microbiota through the administration of probiotics, prebiotics, and or synbiotics (a combination of probiotic and prebiotic) continues to receive much attention for preventing or attenuating the symptoms of metabolicrelated diseases.

\section{Biochemistry of BP}

The maintenance of BP homeostasis is a complex process which is carefully regulated by a variety of inputs. Hypertension or BP, defined as systolic blood pressure (SBP) above $140 \mathrm{mmHg}$ and diastolic blood pressure (DBP) above 90 $\mathrm{mmHg}$, is one of the key risk factors for an individual prone to many diseases including coronary heart disease, cerebral hemorrhage, renal and cardiac failure. ${ }^{22,61,62} \mathrm{BP}$ is controlled by a number of complex biochemical pathways. Typically, the renin-angiotensin system (RAS) is known to play a key role in BP regulation and sodium metabolism. In addition to RAS, the kinin-nitric oxide system, the neutral endopeptidase system, and the endothelin-converting enzyme systems have been shown to produce additional vaso-regulatory peptides. ${ }^{63}$ However, RAS has been identified as one of the major controllers of BP among the others identified; which play a central role in controlling the level of other key vasoactive peptides. ${ }^{63} \mathrm{ACE}$ is a carboxypeptidase responsible for the generation of the potent vasoconstrictor angiotensin II by releasing the C-terminal dipeptide His-Leu from angiotensin I, and is also responsible for the inactivation of the vasodilator bradykinin, which gives rise to a net hypertensive effect. ${ }^{63}$ Together these systems produce a wide array of peptides that collectively regulate $\mathrm{BP}$, electrolyte balance, and fluid equilibrium via membrane bound receptors located in 
different tissues. ${ }^{64}$ RAS comprises of: i) AGT - a globular protein which serves as a substrate for ii) renin - an enzyme that catalyzes the proteolytic conversion of AGT to angiotensin I; iii) ACE (EC 3.4.15.1), a key enzyme of the RAS which controls the arterial BP and water-salt equilibrium in the body; ${ }^{65}$ and iv) angiotensin II receptor. ${ }^{66}$ The inhibition of ACE could lead to antihypertension. Recently, the influence of two sensory receptors for SCFAs (Olfr78 and GPR41) in $\mathrm{BP}$ regulation has been identified. ${ }^{67} \mathrm{BP}$ is a multifactorial trait which is regulated by multiple biochemical pathways and all the networks are firmly interlinked.

\section{Gut microbiota, probiotics, and BP homeostasis}

Genomes of lactic acid bacteria (LAB) encode an array of proteolytic cassettes and peptide transporters. ${ }^{68}$ In general, LAB are cell factories for many proteolytic enzymes (present on cell envelope and intracellular peptidases) which are involved in the hydrolysis of peptide bonds generating short oligopeptides. ${ }^{69,70}$ Probiotics have been reported to exert ACE-inhibitory activity by producing antihypertensive bioactive peptides which are released during protein hydrolysis. ${ }^{10,71}$ Similar to ACE-inhibitory peptides, other peptides, casokinins and lactokinins, are also being released during enzymatic proteolysis of milk proteins and microbial fermentations. ${ }^{72}$ Hence, fermented milk products that are rich in bioactive peptides are considered as natural dietary sources to control hypertension. In addition to that, probiotic cultures with certain traits such as exopolysaccharides, ${ }^{73}$ CLA, ${ }^{74}$ and GABA production ${ }^{22,75}$ positively influence the host lipid metabolism and gut microbial compositions (Figure 1). The SCFAs produced by gut microbes, in particular propionate modulates BP levels via Gpr41 and Olfr78 receptors. Furthermore, Olfr 78 knockout mice with reduced gut microbial biomass upon antibiotic treatment showed elevated BP levels. ${ }^{76}$ Similarly, reduced microbial richness and diversity has been observed in spontaneously hypertensive rats, with an increase in Firmicutes/Bacteroidetes ratio and decrease in acetate, butyrate-producing microbes, ${ }^{77}$ clearly indicating that our gut microbiota are master regulators of hypertension.

\section{Vitamins, minerals, and BP}

Deficiency in vitamin and mineral levels are also involved in developing BP. Vitamin D has been identified as one of the key role-players, among others (vitamin $\mathrm{C}$ and $\mathrm{E}$ ). An insufficient vitamin D level has been observed in $50 \%$ of the world's population and hypovitaminosis $\mathrm{D}$ leads to the development of hypertension. Furthermore, the antihypertensive effects of vitamin $\mathrm{D}$ are mediated by renoprotection, prevention of secondary hyperparathyroidism, vasodilation, suppression of the renin-angiotensin-aldosterone system, and anti-inflammatory effects have also been validated. ${ }^{78,79}$ Studies have shown the association between vitamin D deficiency and elevated BP levels among the individuals tested. ${ }^{78}$

Oral administration of probiotic Lactobacillus reuteri National Collections of Industrial, Marine and Food Bacteria (NCIMB) 30242 (Cardioviva) increased serum vitamin $\mathrm{D}$ levels by $14.9 \mathrm{nmol} / \mathrm{L}$ and the levels of other vitamins (A, E and $\beta$-carotene) were unaffected. ${ }^{80}$ Intensive research is required to understand the vitamin biosynthesis pathways of probiotic bacteria in vivo. Such studies aid us in developing live vitamin delivering cultures to combat vitamin deficiencies in the gut microenviroments. Furthermore, probiotic cultures are known to produce $B$ vitamins such as folate (vitamin $\mathrm{B}_{9}$ ) ${ }^{81}$ and vitamin $\mathrm{B}_{12},{ }^{82,83}$ which could be interesting in cases of vitamin deficiency. Until now only one study had shown the improvement of vitamin D levels upon probiotic administration in human subjects, therefore, there is a need for more clinical trials to support this hypothesis. The beneficial role of probiotics in improving cardiovascular health and in the reduction of BP cannot be ruled out; in order to confirm this role, more extensive studies are needed to understand the mechanisms underlying probiotic action. In a review by Ness et al, some studies have shown an inverse association between plasma vitamin $\mathrm{C}$ levels and $\mathrm{BP}$, and a few reported an inverse association with vitamin C intake. ${ }^{84}$

In a recent meta-analysis, it has been found that a daily dose of vitamin C (500 mg) for a period of 8 weeks significantly reduced DBP by $1.67 \pm 0.72 \mathrm{mmHg} .{ }^{85}$ In contrast, administration of $500 \mathrm{mg}$ of vitamin $\mathrm{C}$ for 5 years had no effect on $\mathrm{BP}^{86}$ In conclusion, the association between vitamin $\mathrm{C}$ and controlling $\mathrm{BP}$ remains unclear due to the inconsistent results observed among research studies. Many minerals are involved in controlling BP levels; among them the major minerals positively involved in BP regulation are potassium, magnesium, and calcium. ${ }^{87} \mathrm{~A}$ study has shown that consumption of yogurt containing probiotic strains (Lactobacillus casei, L. reuteri, and Lactobacillus gasseri) containing yogurt increased apparent calcium absorption in growing rats. ${ }^{88}$ The ability of probiotics and prebiotics to increase micronutrient absorption has been examined in different studies. Although the obtained results were not uniform, an increased rate of mineral absorption was noticed in probiotic groups. ${ }^{89}$ In summary, due to the lack of a large 
number of studies on probiotics and their associative link with increased vitamin levels and mineral absorption, this area is still unclear and a solid conclusion cannot be drawn regarding the role of probiotics with respect to vitamins and minerals. Therefore, it is advisable to monitor the key vitamin and mineral levels in probiotic clinical trials to extrapolate the link between them.

\section{Probiotics as antihypertensive agents}

A substantial body of evidence firmly supports the health benefits and clinical effects associated with probiotics and probiotic fermented foods based on in vitro and in vivo studies. In recent years probiotics and their potential role in maintaining cardiovascular and renal health has received much attention among the scientific communities. Numerous studies have shown either moderate or significant reduction in the ratios of SBP/DBP (Table 1). For example, administration of sour milk fermented with Lactobacillus helveticus LBK$16 \mathrm{H}$ containing bioactive tripeptides (commercialized as Evolus $^{\circledR}$; Valio Dairy, Helsinki, Finland) for 21 weeks reduced the mean SBP to $6.7( \pm 3.0) \mathrm{mmHg}$ in 36 hypertensive subjects when compared to the control groups. ${ }^{26}$ Similarly, a mean reduction of SBP $5.2( \pm 8.1) \mathrm{mmHg}$ and $\mathrm{DBP} 1.7 \mathrm{mmHg}$ has been recorded in borderline hypertensive men (aged 23-59 years) given sour milk fermented with L. helveticus and Saccharomyces cerevisiae containing tripeptides (commercialized as Ameal S; Calpis Food Industry, Tokyo, Japan). ${ }^{90}$ It has been shown that administration of L. casei (LEx) cell lysate reduced BP, triglycerides, plasma cholesterol, and glucose levels when compared with the control group. ${ }^{91}$ In a study, oral administration of probiotic cultures Lactobacillus rhamnosus GG and Streptococcus thermophilus containing milk along with vegan food significantly improved lipid profiles and controlled the coliforms in the colon of rats. ${ }^{92} \mathrm{~L}$. helveticus (LBK-16H strain) fermented sour milk containing ACE-inhibitory tripeptides attenuated the development of hypertension in spontaneously hypertensive rats. ${ }^{93}$ In a study, milk fermented with $L$. casei strain Shirota and Lactococcus lactis YIT 2027 and enriched with GABA (1 mg/mL) significantly reduced the mean SBP $(17.4 \pm 4.3 \mathrm{mmHg})$ and DBP $(7.5 \pm 5.7 \mathrm{mmHg})$ in mildly hypertensive patients. ${ }^{22}$ Furthermore, a meta-analysis based on 14 randomized placebo-controlled clinical trials has shown that probiotic fermented milk significantly reduced both SBP and DBP in prehypertensive and hypertensive subjects. ${ }^{94}$ Tanida et al showed that intraduodenal injection of Lactobacillus johnsonii La1 $\left(1 \times 10^{8-9} \mathrm{CFU} /\right.$ day $)$, or its metabolites, reduced hypertension and renal sympathetic nerve activity in urethane-anesthetized rats. This study suggests that La1 or its metabolites might lower BP by changing autonomic neurotransmission via the central histaminergic nerves and the suprachiasmatic nucleus in rats. ${ }^{95}$ In a double-blind, randomized placebo-controlled trial, consumption of a Lactobacillus plantarum $299 \mathrm{v}\left(2 \times 10^{10} /\right.$ $\mathrm{CFU} / \mathrm{mL} /$ day) fermented food product by 36 smokers for 6 weeks significantly reduced SBP $(13 \pm 4 \mathrm{mmHg}, P<0.001)$. Moreover, significant reductions were also observed in fibrinogen and low-density lipoprotein cholesterol, leptin, IL-6, and F2-isoprostane concentrations, which serve as biochemical markers for lipid peroxidation and oxidative stress. ${ }^{96}$ Lactic acid bacteria are able to metabolize the complex milk protein and aid in the release of short bioactive peptides which have ACE-inhibitory activity, thereby contributing to the modulation of hypertension. ${ }^{71,97,98}$ In another study, fermented soy milk probiotic cocktail (L. casei, Lactobacillus acidophilus, Lactobacillus bulgaricus, S. thermophilus, and Bifidobacterium longum) enriched with whey-separated bioactive peptides with high ACE-inhibitory activity positively reduced SBP in rats after 8 weeks of oral application. ${ }^{99}$ Earlier studies have shown the link between gut microbiota and TMAO levels in developing CVD. In a recent study, subjects who received probiotic $L$. casei Shirota (dose of $6.5 \times 10^{9} \mathrm{CFU}$ thrice a day) for 12 weeks showed reduced levels of TMAO when compared to the control group. ${ }^{100}$ Even though the level of reduction is not significant, it is noteworthy to explore the beneficial role of probiotics in multiple aspects of improving the overall health status.

Altogether these studies support the antihypertensive activity of probiotics and consumption of probiotic fermented foods for improving overall health status and reducing the risk of developing CVDs. It is noteworthy that regulation of hypertension via administration of probiotics is cross-linked with several different mechanisms, such as improving lipid levels, triglyceride levels, bile acid deconjugation, and controlling body mass index (Figure 2). In addition, an increase in absorption of nutrients, phytoestrogens (act as vasodilatory factors), and reduction in plasma glucose levels may also influence the probiotic effect in BP regulation. ${ }^{17,65}$ Furthermore, this area of research needs to be examined thoroughly in more clinical studies to postulate the effect of probiotics in the regulation of hypertension.

\section{Conclusion}

An increasing number of clinical trials supporting the probiotic-dependent attenuation of hypertension and hypercholesterolemia could provide immense support for 


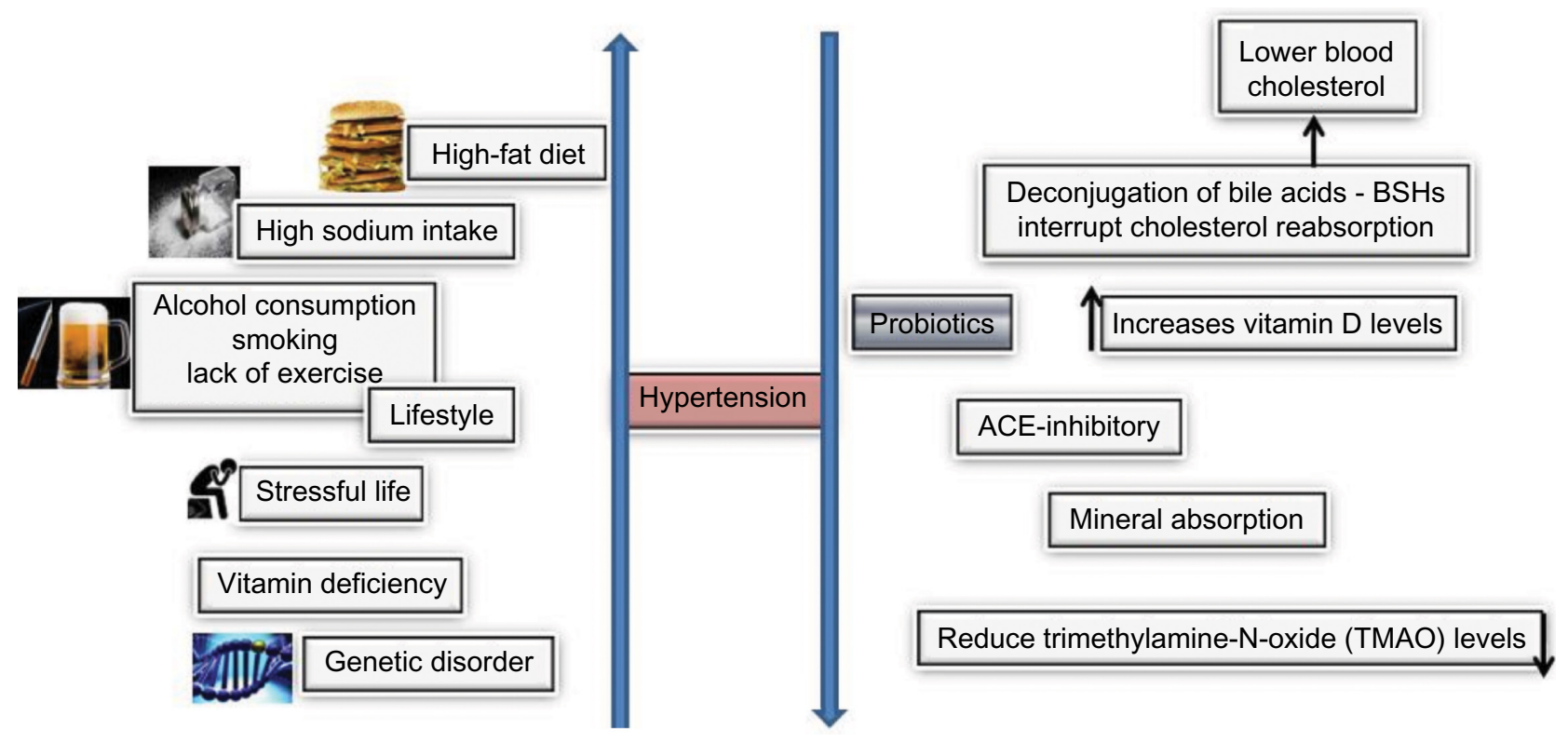

Figure 2 Causative agents of hypertension and potential modes of probiotic action on hypertension. Abbreviation: $\mathrm{BSH}$, bile salt hydrolases.

Table I Anti-hypertensive effect of probiotics or probiotic fermented foods: in vivo studies

\begin{tabular}{|c|c|c|c|c|c|c|}
\hline Beneficial effect & Tested strains & Subjects & Dose (CFU) & Form & Result & Reference \\
\hline $\begin{array}{l}\text { Reduced systolic } \\
\text { blood pressure } \\
\text { (SBP) }\end{array}$ & $\begin{array}{l}\text { Lactobacillus casei } \\
\text { Lactobacillus acidophilus } \\
\text { Lactobacillus rhamnosus } \\
\text { Lactobacillus bulgaricus } \\
\text { Bifidobacterium breve } \\
\text { Bifidobacterium longum } \\
\text { Streptococcus } \\
\text { thermophilus }\end{array}$ & $\begin{array}{l}60 \text { pre-diabetic } \\
\text { patients ( } 25-65 \text { years } \\
\text { old) }\end{array}$ & $\begin{array}{l}7 \times 10^{9} \\
2 \times 10^{9} \\
1.5 \times 10^{9} \\
2 \times 10^{8} \\
2 \times 10^{10} \\
7 \times 10^{9} \\
1.5 \times 10^{10}\end{array}$ & $\begin{array}{l}\text { Capsule }(500 \mathrm{mg}) \\
\text { Prebiotic } \\
\text { Fructooligosaccharide }\end{array}$ & SBP $3.10 \pm 2.2 \mathrm{mmHg}$ & 89 \\
\hline $\begin{array}{l}\text { Hypotensive } \\
\text { effect }\end{array}$ & $\begin{array}{l}\text { S. thermophilus } \\
\text { Lactobacillus delbrueckii } \\
\text { ssp. bulgaricus } \\
\text { L. acidophilus } \\
\text { Lactobacillus kefiri }\end{array}$ & $\begin{array}{l}\text { Meta-analysis } \\
702 \text { human subjects }\end{array}$ & NA & NA & $\begin{array}{l}\text { SBP } 3.1 \pm 1.56 \mathrm{mmHg} \\
\text { DBP } 1.09 \pm 0.06 \mathrm{mmHg}\end{array}$ & 88 \\
\hline $\begin{array}{l}\text { Anti-hypertensive } \\
\text { effect }\end{array}$ & $\begin{array}{l}\text { Lactobacillus helveticus } \\
\text { Saccharomyces } \\
\text { cerevisiae }\end{array}$ & $\begin{array}{l}46 \text { hypertensive men } \\
\text { (aged } 23-59 \text { years) }\end{array}$ & 160 g/day & Sour milk (Ameal S) & $\begin{array}{l}\text { SBP } 5.2 \pm 8.1 \mathrm{mmHg} \\
\text { DBP } 1.7 \mathrm{mmHg}\end{array}$ & 84 \\
\hline $\begin{array}{l}\text { Reduced blood } \\
\text { pressure }\end{array}$ & L. casei & $\begin{array}{l}28 \text { hypertensive } \\
\text { patients } \\
\text { (14 males and } 14 \\
\text { females) }\end{array}$ & NA & $\begin{array}{l}400 \mathrm{mg} \\
\text { cell lysate (LEx) }\end{array}$ & $\begin{array}{l}\text { SBP } 9 \pm 2 \mathrm{mmHg} \\
\mathrm{DBP} 6 \pm 2 \mathrm{mmHg}\end{array}$ & 85 \\
\hline $\begin{array}{l}\text { Reduced blood } \\
\text { pressure levels }\end{array}$ & $\begin{array}{l}\text { L. helveticus } \\
\text { S. cerevisiae }\end{array}$ & $\begin{array}{l}36 \text { hypertensive } \\
\text { subjects } \\
\text { aged } 40-80 \text { years }\end{array}$ & $95 \mathrm{~mL} /$ day & $\begin{array}{l}\text { Fermented milk } \\
\text { (Ameal S) }\end{array}$ & $\begin{array}{l}4 \text { weeks } \\
\text { SBP } 9.4 \pm 3.6 \mathrm{mmHg} \\
8 \text { weeks } \\
\text { SBP } 14.1 \pm 3.1 \mathrm{mmHg} \\
\text { DBP } 6.9 \pm 2.2 \mathrm{mmHg}\end{array}$ & 90 \\
\hline & L. helveticus LBK-16H & $\begin{array}{l}39 \text { hypertensive } \\
\text { subjects }\end{array}$ & $150 \mathrm{~mL} /$ day & $\begin{array}{l}\text { Fermented milk } \\
\left(\text { Evolus }^{\circledR}\right)\end{array}$ & $\begin{array}{l}\text { SBP } 6.7 \pm 3.0 \mathrm{mmHg} \\
\text { DBP } 3.6 \pm 1.9 \mathrm{mmHg}\end{array}$ & 91 \\
\hline $\begin{array}{l}\text { Reduction in high } \\
\text { blood pressure } \\
\text { levels }\end{array}$ & L. helveticus CM4 & $\begin{array}{l}\text { Total } 80 \text { subjects } \\
40 \text { - high-normal BP } \\
40 \text { - mild } \\
\text { hypertension }(\mathrm{MH})\end{array}$ & $12 \mathrm{~g} /$ day & Tablet & $\begin{array}{l}\text { High-normal group } \\
\text { SBP - no significant change } \\
\text { DBP } 5.0 \pm 0.1 \mathrm{mmHg} \\
\text { MH group } \\
\text { SBP II.2 } \pm 4.0 \mathrm{mmHg} \\
\text { DBP } 6.5 \pm 0.1 \mathrm{mmHg}\end{array}$ & 92 \\
\hline
\end{tabular}


Table I (Continued)

\begin{tabular}{|c|c|c|c|c|c|c|}
\hline Beneficial effect & Tested strains & Subjects & Dose (CFU) & Form & Result & Reference \\
\hline $\begin{array}{l}\text { Reduced blood } \\
\text { pressure levels }\end{array}$ & L. helveticus LBK-I6H & $\begin{array}{l}17 \text { mild-hypertensive } \\
\text { subjects }\end{array}$ & $150 \mathrm{~mL} /$ day & $\begin{array}{l}\text { Fermented milk } \\
\left(\text { Evolus }{ }^{\circledR}\right) \\
\text { containing lle-Pro- } \\
\text { Pro and } \\
\text { Val-Pro-Pro } \\
\text { tripeptides }\end{array}$ & $7.3 \%$ reduction & 26 \\
\hline $\begin{array}{l}\text { Lowering blood } \\
\text { pressure }\end{array}$ & $\begin{array}{l}\text { L. casei } \\
\text { Strain Shirota } \\
\text { Lactococcus lactis YIT } \\
2027\end{array}$ & $\begin{array}{l}39 \mathrm{MH} \text { patients } 16 \\
\text { women and } 23 \text { men } \\
\text { (aged between } 28-8 \mathrm{I} \\
\text { years) } \\
\text { Mean age } 54.2 \text { years }\end{array}$ & $100 \mathrm{~mL} /$ day & $\begin{array}{l}\text { Fermented milk } \\
\text { containing GABA }\end{array}$ & $\begin{array}{l}\text { SBP } 17.4 \pm 4.3 \mathrm{mmHg} \\
\text { DBP } 7.2 \pm 5.7 \mathrm{mmHg}\end{array}$ & 22 \\
\hline $\begin{array}{l}\text { Lowers blood } \\
\text { pressure }\end{array}$ & L. helveticus LBK-I6H & $\begin{array}{l}60 \text { subjects ( } 36 \text { men, } \\
24 \text { women) }\end{array}$ & $150 \mathrm{~mL} /$ day & $\begin{array}{l}\text { Fermented milk } \\
\text { containing } \\
2.5-2.7 \mathrm{mg} / 150 \mathrm{~mL} \\
\text { lle-Pro-Pro and } \\
\text { Val-Pro-Pro } \\
\text { tripeptides }\end{array}$ & $\begin{array}{l}10 \text { weeks (mean) } \\
\text { SBP } 2.3 \mathrm{mmHg} \\
\text { DBP } \pm 0.5 \mathrm{mmHg}\end{array}$ & 93 \\
\hline $\begin{array}{l}\text { Reduces blood } \\
\text { pressure, } \\
\text { triglyceride, and } \\
\text { cholesterol levels }\end{array}$ & $\begin{array}{l}\text { Group I } \\
\text { S. thermophilus } \\
\text { ( } 2 \text { cultures) + } \\
\text { L. acidophilus } \\
\text { ( } 2 \text { cultures) } \\
\text { Group } 2 \\
\text { S. thermophilus } \\
\text { ( } 2 \text { cultures) + } \\
\text { Enterococcus faecium } \\
\text { (Causido }^{\circledR} \text { ) GAIO } \\
\text { Group } 3 \\
\text { S. thermophiles } \\
\text { ( } 2 \text { cultures) + } \\
\text { L. rhamnosus }\end{array}$ & $\begin{array}{l}70 \text { healthy, } \\
\text { overweight, and } \\
\text { obese subjects } \\
20 \text { males } \\
50 \text { females } \\
18-55 \text { years old }\end{array}$ & $450 \mathrm{~mL} /$ day & $\begin{array}{l}\text { Fermented milk } \\
\text { (yogurt) }\end{array}$ & $\begin{array}{l}8 \text { weeks mean } \\
\text { Group I } \\
\Delta \text { SBP } 4.4 \pm 1.8 \mathrm{mmHg} \\
\Delta \text { DBP } 3.4 \pm 1.5 \mathrm{mmHg} \\
\text { Group } 2 \\
\Delta \text { SBP } 8.0 \pm 2.3 \mathrm{mmHg} \\
\Delta \text { DBP } 4.0 \pm 2.3 \mathrm{mmHg} \\
\text { Group } 3 \\
\Delta \text { SBP } 2.6 \pm 3.1 \mathrm{mmHg} \\
\Delta \text { DBP } 0.8 \pm 2.0 \mathrm{mmHg}\end{array}$ & 94 \\
\hline $\begin{array}{l}\text { Significant } \\
\text { reduction in SBP, } \\
\text { cholesterol, and } \\
\text { triglyceride levels }\end{array}$ & $\begin{array}{l}\text { S. thermophilus } \\
\text { TMCI } 543 \\
\text { L. casei TMC0409 }\end{array}$ & 20 healthy adults & $\begin{array}{l}200 \mathrm{~mL} / \text { day } \\
6.8 \times 10^{8} / \mathrm{mL} \\
\text { and } 2.6 \times 10^{7} \\
\text { respectively }\end{array}$ & $\begin{array}{l}\text { Fermented milk } \\
\text { containing whey } \\
\text { protein concentrate }\end{array}$ & $\begin{array}{l}\text { Significant reduction in SBP } \\
(P<0.05)\end{array}$ & 101 \\
\hline $\begin{array}{l}\text { Reduced blood } \\
\text { pressure and } \\
\text { body mass } \\
\text { indexes }\end{array}$ & $\begin{array}{l}\text { Lactobacillus plantarum } \\
\text { TENSIA }\end{array}$ & 40 subjects & $50 \mathrm{~g} /$ day & Probiotic cheese & $\begin{array}{l}\text { Morning } \\
\Delta \text { SBP I } 2.2 \pm 1.5 \mathrm{mmHg} \\
\Delta \text { DBP } 4.0 \pm 0.9 \\
\text { Evening } \\
\Delta \text { SBP } 8.8 \pm 0.9 \mathrm{mmHg} \\
\Delta \text { DBP } 1.6 \pm 1.2 \mathrm{mmHg}\end{array}$ & 102 \\
\hline
\end{tabular}

Abbreviations: DBP, diastolic blood pressure; SBP, systolic blood pressure; NA, not available.

the application of such cultures to improve cardiovascular health. Hence, dietary intervention to correct gut microbiota could be an innovative nutritional therapeutic strategy for hypertension. The knowledge obtained on probiotic potential against CVDs is still at infancy stage and current findings suggest that hypotensive effects of probiotics are very promising and worth exploring to promote cardiovascular health.

However, more studies are required for a better understanding of gut microbiota-host crosstalk and biochemical networks underlying control of hypertension. As BP is interlinked with other metabolic disorders, it is necessary to examine the outcomes in a meticulous manner to get a clear picture of probiotic action against CVDs.

\section{Disclosure}

The authors have no conflicts of interest to disclose.

\section{References}

1. Sanders ME, Guarner F, Guerrant R, et al. An update on the use and investigation of probiotics in health and disease. Gut. 2013;62(5): 787-796. 
2. Isolauri E, Sütas Y, Kankaanpää P, Arvilommi H, Salminen S. Probiotics: effects on immunity. Am J Clin Nutr. 2001;73(2 Suppl): 444S-450S.

3. Klaenhammer TR, Kleerebezem M, Kopp MV, Rescigno M. The impact of probiotics and prebiotics on the immune system. Nat Rev Immunol. 2012;12(10):728-734.

4. Food and Agriculture Organization of the United Nations/World Health Organization. Report of a joint FAO/WHO expert consultation on evaluation of health and nutritional properties of probiotics in food including powder milk with live lactic acid bacteria. FAO/WHO; 2001. Available from: ftp://ftp.fao.org/docrep/fao/009/a0512e/a0512e00.pdf. Accessed December 19, 2015.

5. Alakomi HL, Skytta E, Saarela M, Mattila-Sandholm T, LatvaKala K, Helander IM. Lactic acid permeabilizes gram-negative bacteria by disrupting the outer membrane. Appl Environ Microbiol. 2000;66(5):2001-2005.

6. Atassi F, Servin AL. Individual and co-operative roles of lactic acid and hydrogen peroxide in the killing activity of enteric strain Lactobacillus johnsonii ncc933 and vaginal strain Lactobacillus gasseri ks120.1 against enteric, uropathogenic and vaginosis-associated pathogens. FEMS Microbiol Lett. 2010;304(1):29-38.

7. Corr SC, Li Y, Riedel CU, O’Toole PW, Hill C, Gahan CG. Bacteriocin production as a mechanism for the antiinfective activity of Lactobacillus salivarius UCC118. Proc Natl Acad Sci U S A. 2007;104(18):7617-7621.

8. Dobson A, Cotter PD, Ross RP, Hill C. Bacteriocin production: A probiotic trait? Appl Environ Microbiol. 2012;78(1):1-6.

9. Naidu AS, Bidlack WR, Clemens RA. Probiotic spectra of lactic acid bacteria (lab). Crit Rev Food Sci Nutr. 1999;39(1):13-126.

10. Stanton C, Ross RP, Fitzgerald GF, Sinderen DV. Fermented functional foods based on probiotics and their biogenic metabolites. Curr Opin Biotechnol. 2005;16(12):198-203.

11. Vandenbergh PA. Lactic acid bacteria, their metabolic products and interference with microbial growth. FEMS Microbiology Reviews. 1993;12(1-3):221-237.

12. Barrett E, Ross RP, O’Toole PW, Fitzgerald GF, Stanton C. $\gamma$-Aminobutyric acid production by culturable bacteria from the human intestine. J Appl Microbiol. 2012;113(2):411-417.

13. Upadrasta A, Stanton C, Hill C, Fitzgerald G, Ross RP. Improving the stress tolerance of probiotic cultures: Recent trends and future directions. In: Tsakalidou E, Papadimitriou K, editors. Stress responses of lactic acid bacteria. Springer US; 2011:395-438.

14. Sudha RM, Bhonagiri S. Efficacy of Bacillus coagulans strain unique is-2 in the treatment of patients with acute diarrhea. International Journal of Probiotics and Prebiotics. 2012;7(1):33-37.

15. Ettinger G, MacDonald K, Reid G, Burton JP. The influence of the human microbiome and probiotics on cardiovascular health. Gut Microbes. 2014;5(6):719-728.

16. Fariborz A, Aziz H. Dairy probiotic foods and coronary heart disease: A review on mechanism of action. Intech; 2012.

17. Khalesi S, Sun J, Buys N, Jayasinghe R. Effect of probiotics on blood pressure: a systematic review and meta-analysis of randomized, controlled trials. Hypertension. 2014;64(4):897-903.

18. Liong MT. Probiotics: a critical review of their potential role as antihypertensives, immune modulators, hypocholesterolemics, and perimenopausal treatments. Nutr Rev. 2007;65(7):316-328.

19. Lye HS, Kuan CY, Ewe JA, Fung WY, Liong MT. The improvement of hypertension by probiotics: Effects on cholesterol, diabetes, renin, and phytoestrogens. Int J Mol Sci. 2009;10(9):3755-3775.

20. Kearney PM, Whelton M, Reynolds K, Muntner P, Whelton PK, He J. Global burden of hypertension: analysis of worldwide data. Lancet. 2005;365(9455):217-223.

21. Hayakawa K, Kimura M, Kasaha K, Matsumoto K, Sansawa H, Yamori Y. Effect of a gamma-aminobutyric acid-enriched dairy product on the blood pressure of spontaneously hypertensive and normotensive wistar-kyoto rats. Br J Nutr. 2004;92(3):411-417.
22. Inoue $\mathrm{K}$, Shirai $\mathrm{T}$, Ochiai $\mathrm{H}$, et al. Blood-pressure-lowering effect of a novel fermented milk containing [gamma]-aminobutyric acid (gaba) in mild hypertensives. Eur J Clin Nutr. 2003;57(3): 490-495.

23. Hennessy AA, Ross RP, Devery R, Stanton C. The health promoting properties of the conjugated isomers of alpha linolenic acid. Lipids. 2011;46(2):105-119.

24. Hernández-Ledesma B, Amigo L, Ramos M, Recio I. Angiotensin converting enzyme inhibitory activity in commercial fermented products. Formation of peptides under simulated gastrointestinal digestion. J Agric Food Chem. 2004;52(6):1504-1510.

25. Okamoto A, Hanagata H, Matsumoto E, Kawamura Y, Koizumi Y, Yanagida F. Angiotensin I converting enzyme inhibitory activities of various fermented foods. Biosci Biotechnol Biochem. 1995;59(6): 1147-1149.

26. Seppo L, Kerojoki O, Suomalainen T, Korpela R. The effect of a Lactobacillus helveticus $1 \mathrm{bk}-16 \mathrm{~h}$ fermented milk on hypertension: A pilot study on humans. Milchwissenschaft. 2002;57(3):124-127.

27. Stanton C, Gardiner G, Meehan H, et al. Market potential for probiotics. Am J Clin Nutr. 2001;73(2 Suppl):476S-483S.

28. Ross RP, Fitzgerald G, Collins K, Stanton C. Cheese delivering biocultures--probiotic cheese. Australian Journal of Dairy Technology. 2002;57:71-78.

29. Xiao JZ, Kondo S, Takahashi N, et al. Effects of milk products fermented by Bifidobacterium longum on blood lipids in rats and healthy adult male volunteers. J Dairy Sci. 2003;86(7):2452-2461.

30. Itsaranuwat P, Al-Haddad KS, Robinson RK. The potential therapeutic benefits of consuming 'health-promoting' fermented dairy products: a brief update. International Journal of Dairy Technology. 2003;56(4):203-210.

31. Gawkowski D, Chikindas ML. Non-dairy probiotic beverages: the next step into human health. Benef Microbes. 2013;4(2):127-142.

32. Gill SR, Pop M, DeBoy RT, et al. Metagenomic analysis of the human distal gut microbiome. Science. 2006;312(5778):1355-1359.

33. Eckburg PB, Bik EM, Bernstein CN, et al. Diversity of the human intestinal microbial flora. Science. 2005;308(5728):1635-1638.

34. Bocci V. The neglected organ: bacterial flora has a crucial immunostimulatory role. Perspect Biol Med. 1992;35(2):251-260.

35. O'Hara AM, Shanahan F. The gut flora as a forgotten organ. $E M B O$ Rep. 2006;7(7):688-693.

36. Costello EK, Stagaman K, Dethlefsen L, Bohannan BJM, Relman DA. The application of ecological theory toward an understanding of the human microbiome. Science. 2012;336(6086):1255-1262.

37. Walter J, Ley R. The human gut microbiome: Ecology and recent evolutionary changes. Annu Rev Microbiol. 2011;65:411-429.

38. Bäckhed F, Roswall J, Peng Y, et al. Dynamics and stabilization of the human gut microbiome during the first year of life. Cell Host Microbe. 2015;17(5):690-703.

39. Dogra S, Sakwinska O, Soh SE, et al. Dynamics of infant gut microbiota are influenced by delivery mode and gestational duration and are associated with subsequent adiposity. MBio. 2015;6(1). pii: e02419-e02414.

40. Kalliomäki M, Carmen Collado M, Salminen S, Isolauri E. Early differences in fecal microbiota composition in children may predict overweight. Am J Clin Nutr. 2008;87(3):534-538.

41. Aagaard K, Ma J, Antony KM, Ganu R, Petrosino J, Versalovic J. The placenta harbors a unique microbiome. Sci Transl Med. 2014;6:(237):237ra65.

42. Turnbaugh PJ, Ley RE, Mahowald MA, Magrini V, Mardis ER, Gordon JI. An obesity-associated gut microbiome with increased capacity for energy harvest. Nature. 2006;444(7122):1027-1131.

43. Larsen N, Vogensen FK, van den Berg FW, et al. Gut microbiota in human adults with type 2 diabetes differs from non-diabetic adults. PloS One. 2010;5(2):e9085.

44. Qin J, Li Y, Cai Z, et al. A metagenome-wide association study of gut microbiota in type 2 diabetes. Nature. 2012;490(7418):55-60. 
45. Cryan JF, O'Mahony SM. The microbiome-gut-brain axis: from bowel to behavior. Neurogastroenterol Motil. 2011;23(3):187-192.

46. Foster JA, Neufeld KA. Gut-brain axis: how the microbiome influences anxiety and depression. Trends Neurosci. 2013;36(5): 305-312.

47. Mulle JG, Sharp WG, Cubells JF. The gut microbiome: a new frontier in autism research. Curr Psychiatry Rep. 2013;15(2):337.

48. Tilg H, Kaser A. Gut microbiome, obesity, and metabolic dysfunction. J Clin Invest. 2011;121(6):2126-2132.

49. Vijay-Kumar M, Aitken JD, Carvalho FA, et al. Metabolic syndrome and altered gut microbiota in mice lacking toll-like receptor 5. Science. 2010;328(5975):228-231

50. Bennett BJ, de Aguiar Vallim TQ, Wang Z, et al. Trimethylaminen-oxide, a metabolite associated with atherosclerosis, exhibits complex genetic and dietary regulation. Cell Metab. 2013;17(1):49-60.

51. Wang Z, Klipfell E, Bennett BJ, et al. Gut flora metabolism of phosphatidylcholine promotes cardiovascular disease. Nature. 2011;472(7341):57-63.

52. Zhu Y, Jameson E, Crosatti M, Schäfer H, Rajakumar K, Bugg TDH, Chen Y. Carnitine metabolism to trimethylamine by an unusual riesketype oxygenase from human microbiota. Proc Natl Acad Sci U S A. 2014;111(11):4268-4273.

53. Appel LJ, Brands MW, Daniels SR, et al. Dietary approaches to prevent and treat hypertension a scientific statement from the American heart association. Hypertension. 2006;47(2):296-308.

54. Appel LJ, Moore TJ, Obarzanek E, et al. A clinical trial of the effects of dietary patterns on blood pressure. $N$ Engl $J$ Med 1997;336(16):1117-1124.

55. Bernstein AM, Sun Q, Hu FB, Stampfer MJ, Manson JE, Willett WC Major dietary protein sources and risk of coronary heart disease in women. Circulation. 2010;122(9):876-883.

56. Jenkins DJ, Kendall CW, Marchie A, et al. The Garden of Eden-plant based diets, the genetic drive to conserve cholesterol and its implications for heart disease in the 21 st century. Comp Biochem Physiol $A$ Mol Integr Physiol. 2003;136(1):141-151.

57. Micha R, Wallace SK, Mozaffarian D. Red and processed meat consumption and risk of incident coronary heart disease, stroke, and diabetes mellitus a systematic review and meta-analysis. Circulation. 2010;121(21):2271-2283.

58. Koeth RA, Wang Z, Levison BS, et al. Intestinal microbiota metabolism of 1-carnitine, a nutrient in red meat, promotes atherosclerosis. Nat Med. 2013;19(5):576-585.

59. Miura K, Greenland P, Stamler J, Liu K, Daviglus ML, Nakagawa H. Relation of vegetable, fruit, and meat intake to 7-year blood pressure change in middle-aged men the Chicago western electric study. Am J Epidemiol. 2004;159(6):572-580.

60. Shanahan F, McCarthy J. Functional foods and probiotics: time for gastroenterologists to embrace the concept. Curr Gastroenterol Rep. 2000;2(5):345-346.

61. Peters J. Molecular basis of human hypertension: the role of angiotensin Baillières Clin Endocrinol Metab. 1995;9(3):657-678.

62. Marc Y, Llorens-Cortes C. The role of the brain renin-angiotensin system in hypertension: implications for new treatment. Prog Neurobiol. 2011;95(2):89-103.

63. FitzGerald RJ, Murray BA, Walsh DJ. Hypotensive peptides from milk proteins. J Nutr. 2004;134(4):980S-988S

64. Morgan L, Pipkin FB, Kalsheker N. Angiotensinogen: molecular biology, biochemistry and physiology. Int $J$ Biochem Cell Biol. 1996;28(11):1211-1222.

65. Ebel B, Lemetais G, Beney L, et al. Impact of probiotics on risk factors for cardiovascular diseases. A review. Crit Rev Food Sci Nutr. 2014;54(2):175-189.

66. Griendling KK, Murphy TJ, Alexander RW. Molecular biology of the renin-angiotensin system. Circulation. 1993;87(6):1816-1828.

67. Pluznick J. A novel SCFA receptor, the microbiota, and blood pressure regulation. Gut Microbes. 2014;5(2):202-207.
68. Liu M, Bayjanov JR, Renckens B, Nauta A, Siezen RJ. The proteolytic system of lactic acid bacteria revisited: a genomic comparison. $B M C$ Genomics. 2010;11:36.

69. Hooper LV, Littman DR, Macpherson AJ. Interactions between the microbiota and the immune system. Science. 2012;336(6086): $1268-1273$.

70. Gordon JI. Honor thy gut symbionts redux. Science. 2012;336(6086): 1251-1253.

71. Korhonen H. Milk-derived bioactive peptides: From science to applications. Journal of Functional Foods. 2009;1(2):177-187.

72. FitzGerald RJ, Meisel H. Milk protein-derived peptide inhibitors of angiotensin-I-converting enzyme. Br J Nutr. 2000;84 Suppl 1:S33-37.

73. London LEE, Kumar AHS, Wall R, et al. Exopolysaccharide-producing probiotic lactobacilli reduce serum cholesterol and modify enteric microbiota in ApoE-deficient mice. J Nutr. 2015;144(12): 1956-1962.

74. Marques TM, Wall R, O'Sullivan O, et al. Dietary trans-10, cis-12conjugated linoleic acid alters fatty acid metabolism and microbiota composition in mice. Br J Nutr. 2015;113(5):728-738.

75. Lyte M, Cryan JF, Wall R, et al. Bacterial neuroactive compounds produced by psychobiotics. Adv Exp Med Biol. 2014;817: 221-239.

76. Pluznick JL, Protzko RJ, Gevorgyan H, et al. Olfactory receptor responding to gut microbiota-derived signals plays a role in renin secretion and blood pressure regulation. Proc Natl Acad Sci U S A. 2013;110(11):4410-4415.

77. Yang T, Santisteban MM, Rodriguez V, et al. Gut dysbiosis is linked to hypertension. Hypertension. 2015;65(6):1331-1340.

78. Pilz S, Tomaschitz A, Ritz E, Pieber TR. Vitamin D status and arterial hypertension: a systematic review. Nat Rev Cardiol. 2009;6(10):621-630.

79. Kienreich K, Tomaschitz A, Verheyen N, et al. Vitamin D and cardiovascular disease. Nutrients. 2013;5(8):3005-3021.

80. Jones ML, Martoni CJ, Prakash S. Oral supplementation with probiotic L. reuteri $\mathrm{NCIMB} 30242$ increases mean circulating 25 -hydroxyvitamin D: a post hoc analysis of a randomized controlled trial. J Clin Endocrinol Metab. 2013;98(7):2944-2951.

81. Santos F, Wegkamp A, de Vos WM, Smid EJ, Hugenholtz J. High-level folate production in fermented foods by the B12 producer Lactobacillus reuteri JCM1112. Appl Environ Microbiol. 2008;74(10): 3291-3294.

82. Taranto MP, Vera JL, Hugenholtz J, De Valdez GF, Sesma F. Lactobacillus reuteri CRL1098 produces cobalamin. J Bacteriol. 2003;185(18):5643-5647.

83. Santos F, Vera JL, van der Heijden R, et al. The complete coenzyme b12 biosynthesis gene cluster of Lactobacillus reuteri CRL1098. Microbiology. 2008;154(Pt 1):81-93.

84. Ness AR, Chee D, Elliott P. Vitamin C and blood pressure--an overview. J Hum Hypertens. 1997;11(6):343-350.

85. Juraschek SP, Guallar E, Appel LJ, Miller ER 3rd. Effects of vitamin C supplementation on blood pressure: a meta-analysis of randomized controlled trials. Am J Clin Nutr. 2012;95(5):1079-1088.

86. Kim MK, Sasaki S, Sasazuki S, Okubo S, Hayashi M, Tsugane S. Lack of long-term effect of vitamin c supplementation on blood pressure. Hypertension. 2002;40(6):797-803.

87. Houston MC. Treatment of hypertension with nutraceuticals, vitamins, antioxidants and minerals. Expert Rev Cardiovasc Ther. 2007;5(4):681-691.

88. Ghanem KZ, Badawy IH, Abdel-Salam AM. Influence of yoghurt and probiotic yoghurt on the absorption of calcium, magnesium, iron and bone mineralization in rats. Milchwissenschaft. 2004;59(9): 472-475.

89. Sheridan PO, Bindels LB, Saulnier DM, et al. Can prebiotics and probiotics improve therapeutic outcomes for undernourished individuals? Gut Microbes. 2014;5(1):74-82. 
90. Mizushima S, Ohshige K, Watanabe J, et al. Randomized controlled trial of sour milk on blood pressure in borderline hypertensive men. Am J Hypertens. 2004;17(8):701-706.

91. Nakajima K, Hata Y, Osono Y, Hamura M, Kobayashi S, Watanuki M. Antihypertensive effect of extracts of Lactobacillus casei in patients with hypertension. Journal of Clinical Biochemistry and Nutrition. 1995;18(3):181-187.

92. Al-Okbi SY, Mohamad D, Hamed T, Afifi AA, Mohamad SH. Reduction of the risk of cardiovascular diseases through dietary mixtures and probiotic. The Medical Journal of Cairo University. 2010;78(2).

93. Sipola M, Finckenberg P, Santisteban J, Korpela R, Vapaatalo H, Nurminen M-L. Long-term intake of milk peptides attenuates development of hypertension in spontaneously hypertensive rats. $J$ Physiol Pharmacol. 2001;52:745-754

94. Dong JY, Szeto IM, Makinen K, et al. Effect of probiotic fermented milk on blood pressure: a meta-analysis of randomised controlled trials. Br J Nutr. 2013;110(7):1188-1194.

95. Tanida M, Yamano T, Maeda K, Okumura N, Fukushima Y, Nagai K. Effects of intraduodenal injection of Lactobacillus johnsonii la1 on renal sympathetic nerve activity and blood pressure in urethane-anesthetized rats. Neurosci Lett. 2005;389(2):109-114.

96. Naruszewicz M, Johansson ML, Zapolska-Downar D, Bukowska H. Effect of Lactobacillus plantarum $299 \mathrm{v}$ on cardiovascular disease risk factors in smokers. Am J Clin Nutr. 2002;76(6):1249-1255.
97. Donkor ON, Henriksson A, Singh TK, Vasiljevic T, Shah NP. Aceinhibitory activity of probiotic yoghurt. International Dairy Journal. 2007;17(11):1321-1331.

98. Hayes M, Stanton C, Slattery H, et al. Casein fermentate of Lactobacillus animalis DPC6134 contains a range of novel propeptide angiotensin-converting enzyme inhibitors. Appl Environ Microbiol. 2007;73(14):4658-4667.

99. Tsai JS, Lin YS, Pan BS, Chen TJ. Antihypertensive peptides and $\gamma$-aminobutyric acid from prozyme 6 facilitated lactic acid bacteria fermentation of soymilk. Process Biochemistry. 2006;41(6):1282-1288.

100. Tripolt NJ, Leber B, Triebl A, Köfeler H, Stadlbauer V, Sourij H. Effect of Lactobacillus casei Shirota supplementation on trimethylaminen-oxide levels in patients with metabolic syndrome: An open-label, randomized study. Atherosclerosis. 2015;242(1):141-144.

101. Kawase M, Hashimoto H, Hosoda M, Morita H, Hosono A. Effect of administration of fermented milk containing whey protein concentrate to rats and healthy men on serum lipids and blood pressure. J Dairy Sci. 2000;83(2):255-263.

102. Sharafedtinov KK, Plotnikova OA, Alexeeva RI, et al. Hypocaloric diet supplemented with probiotic cheese improves body mass index and blood pressure indices of obese hypertensive patients-a randomized double-blind placebo-controlled pilot study. Nutr J. 2013;12:138.
Integrated Blood Pressure Control

\section{Publish your work in this journal}

Integrated Blood Pressure Control is an international, peer-reviewed open-access journal focusing on the integrated approach to managing hypertension and risk reduction. Treating the patient and comorbidities together with diet and lifestyle modification and optimizing healthcare resources through a multidisciplinary team approach constitute key

\section{Dovepress}

features of the journal. This journal is indexed on American Chemical Society's Chemical Abstracts Service (CAS). The manuscript management system is completely online and includes a very quick and fair peerreview system, which is all easy to use. Visit http://www.dovepress.com/ testimonials.php to read real quotes from published authors. 